\title{
Corporate Governance Failure: The Case Of Enron And Parmalat
}

\author{
Rezart Dibra, PhD
}

Albania Professional Business Academy, Tirana, Albania

doi: 10.19044/esj.2016.v12n16p283 URL:http://dx.doi.org/10.19044/esj.2016.v12n16p283

\section{Abstract}

Corporate governance is a central and dynamic aspect of business. The term governance is derived from the latin word gubernare, meaning to steer. It usually applies to the steering of a ship. Thus, this implies that corporate governance involves the function of direction rather than control. Corporate governance has come to the forefront of academic research due to the vital role it plays in the overall health of economic systems. Corporate governance was long ignored as a matter of potential importance for the development of a nation's economy. The wave of U.S. corporate fraud in the 1990s was attributed to deficiencies in corporate governance. The recent 2008-2009 global financial crisis, triggered by the unprecedented failure of Lehman Brothers and the subprime mortgage problems, renewed interest on the role of corporate governance in the financial sector. The development of a strong corporate governance framework is important to protect stakeholders, maintain investor confidence in the transition countries, and attract foreign direct investment. This paper looks at the collapse of Enron and the Parmalat, which was a particular Italian scandal. Parmalat, Enron, and other American firms such as Tyco and WorldCom all have a number of fudging at their core - efforts to make the companies look healthier than they were. Parmalat's collapse began in November when its auditor raised questions about a \$135 million derivatives profit. After additional evidence of accounting misstatements, the company's chief executive and founder, Calisto Tanzi, resigned on the $15^{\text {th }}$ of December. Four days later, the company disclosed the fake Bank of America letter. On the $23^{\text {rd }}$ of December, Italian investigators stated that the company had used dozens of offshore companies to report non-existent assets to offset themselves. This was as much as $\$ 11$ billion in liabilities. Also, this is in addition to the fact that Parmalat might have been falsifying its accounting figures for as long as 15 years. 
Keywords: Corporate governance, transition countries, emerging economies

\section{Introduction}

Corporate governance is a central and dynamic aspect of business. The importance of corporate governance for corporate success as well as for social welfare cannot be overstated. Examples of massive corporate collapses resulting from weak systems of corporate governance have highlighted the need to improve and reform corporate governance at the international level. In the wake of Enron, Parmalat and other similar cases, countries around the world have reacted quickly by pre-empting similar events domestically. As a speedy response to these corporate failures, the USA issued the Sarbanes Oxley Act in July 2002. In January 2003, the Higgs Report and the Smith Report were published in the UK. This publication again was in response to the recent corporate governance failures.

Consequently, corporate governance has become one of the most commonly used phrases in the current global business vocabulary. The notorious collapse of Enron 2001, one of America's largest companies, has focused international attention on company failures. In addition, it also presents the role that strong corporate governance play in preventing these failures.

"Corporate governance" comprises of a country's private and public institutions, both formal and informal, which together govern the relationship between the people who manage corporations (corporate insiders) and all others who invest resources in various corporations in the country.

Therefore, corporate governance generally refers to the set of rulebased processes of laws, policies, and accountability that governs the relationship between the investor (stockholder of a company) and the investee (management). Corporate governance attracts a great deal of attention in the aftermath of the Asian financial crisis of 1997-1998 and the early 2000s U.S. corporate scandals, like Enron and WorldCom. However, after the threat of global contagion financial crises passed, corporate governance was relegated to the back of academic research.

Therefore, the focus of this paper is to analyze the challenges that transition countries faces when moving from a politically-based relationship to a relationship that is rule-based. Furthermore, it also analyses the role of corporate governance as a major factor in the unprecedented transformation of transition countries to a market economy.

\section{The Collapse of Enron}

In 2001, Enron became a household name - and probably in most households in most countries around the world. 
On the $2^{\text {nd }}$ of December 2001, Enron became one of the 10 largest companies in the USA. In the following months, more and more evidence emerged about the weaknesses and fraudulent activity of corporate governance. However, countries across the world have been unsettled and disturbed by the shock of this event and are now examining their own corporate governance systems in micro-detail. This they do by looking for similar weaknesses and potential like Enrons. Enronitis has spread across the globe like a lethal virus, infecting every company and every shareholding institutions. In addition, it also had a significant effect on worrying even by the smallest shareholder and unnerving the financial markets.

Enron was a Huston-based energy company founded by a brilliant entrepreneur, Kenneth Lay. The company was created in 1985 by a merger of two American gas pipeline companies. Within a period of 16 years, the company was transformed from a relatively small concern, involved in gas pipelines, and oil and gas exploration, to the world's largest energy trading company (The Economist, 28 November 2002). Enron, the champion of energy deregulation that grew into one of the nation's 10 largest companies, collapsed yesterday. This collapse occurred after a rival backed out of a deal to buy Enron, and after many big trading partners stopped doing business with the company.

Enron, based in Houston, has been widely expected to seek bankruptcy protection. With $\$ 62$ billion in assets as of September 30, it would be the biggest American company ever to go bankrupt. Hence, this company dwarfs the filing by Texaco in 1987. Late in the day, Enron's chief financial officer, Jeff McMahon, stated that the company was still talking to banks about a restructuring and a consideration of other options.

The role of a company's board of directors is to oversee corporate management in order to protect the interests of shareholders. However, in 1999, Enron's board waived conflict of interest rules to allow chief financial officer, Andrew Fastow, to create private partnerships to do business with the firm. These partnerships appear to have concealed debts and liabilities that would have had a significant impact on Enron's reported profits. Subsequently, Enron's collapse raises the issue of how to reinforce the directors' capability and will to challenge questionable dealings through corporate managers.

Several corporate governance problems have emerged due to Enron's wreckage. Unfettered power in the hand of the chief executive is an obvious problem, and is one that characterized Enron's management. Also, there were numerous illustrations of unethical activity within the Enron organization that continued to come to light long after its downfall. For example, in May 2002, it became clear from the documents released by the Federal Energy Regulatory Commission that Enron's energy traders 
developed and used strategies or tricks to manipulate the markets where Califonia bought electricity.

Overall, corporate governance in Enron was weak in almost all aspects. Thus, the board of directors is composed of a number of people who lacks moral character. Also, they are often willing to engage themselves in fraudulent activity. This was the genuine root of the company's corporate governance failure.

There has been a proliferation of books on the downfall of Enron, seeking to explain why events transpired as they did. As we have seen, the USA and the UK strong reaction to Enron's collapse and corporate governance has been hurled to the centre stage. This occurs as a result of the weaknesses at the heart of Enron's corporate governance system. The longterm effects of Enron will hopeful be a cleaner and more ethical corporate environment across the globe. Furthermore, the continuous updating of corporate governance codes of practice and systematic review of corporate governance checks and balances are necessary to avoid other Enrons in the future.

Clearly, corporate governance check and balances can only serve to detect, not cure, unethical practices. A complicating factor in issues of fraud and ethical breakdown is the intangible nature of fraud. In addition, there is a grey area surrounding what is right or wrong, good or bad in human behaviour. Some comments made by Sheldon Zenner, an American whitecollar criminal and civil lawyer, when speaking of the Enron trial, helped to illuminate this issue.

\section{Corporate Governance Failure in Parmalat}

Separation of ownership and control in a large stock corporation would be of no particular consequence if the interests of owners and managers coincided. Corporate governance is concerned with overcoming the problems of the monitoring and controlling of managerial performance. This occurs whenever corporate ownership and corporate control are separated as a result of dispersed share ownership. The primary function of corporate governance is to ensure that companies are runned based on the interests of corporate shareholders. However, these shareholders provide financial resources in running them. In the UK and US, owners of typical corporation are many, and their shares are small relative to the size of the corporation.

The collapse of Enron during 2001 has brought about a focused attention on the effectiveness of the non-executive director function. The corporate board, with its mix of expertise, independence, and legal power, is a potentially powerful governance mechanism. 
Parmalat Finanziara, the Italian dairy and food giant, is fast joining Enron and WorldCom as a household name for corporate scandal. The alleged financial fraud at Parmalat spans more than a decade. Also, it involves sums whose estimates have ballooned from EUR 4 billion to more than EUR 8 billion. Founder, chairman, and chief executive Calisto Tanzi has been ousted from the company and board and is under arrest. Enrico Bondi, who replaced Tanzi in December, has been given new authority to act as the sole administrator of Parmalat. Therefore, he has 180 days to save what he can of the company.

While Bondi races against time to unearth the sources of the scandal, some corporate governance experts are already drawing lessons.

The media have termed parmalat, a particular Italian scandal, and have suggested that the situation was more likely to arise in a country like Italy than elsewhere (Mulligan \& Munchau, 2003; Melis, 2005). Given the criticisms of Italian corporate governance in the literature, this is not surprising (Melings, 2005; La Porta et al., 1997).

Parmalat was owned by a complex group of companies. In addition, it is controlled by one strong blockholder (the founding Tanzi family) through pyramidal structure (see Melis 2005). Indeed, Melis (1999) explained that such ownership structures with opaque patterns of ownership and control are not uncommon in Italian companies. Furthermore, Melis (2000) stated that the weaknesses of Anglo Saxon systems of corporate governance were traditionally strong managers: strong blockholders and unprotected minority shareholders. The case of Parmalat was typical of this form of corporate governance. This is with controlling Tanzi shareholders channeling corporate resources illegally to themselves, at the expense of minority shareholders (Melis, 2005).

Although Italian corporate governance is characterized by monitors, namely the statutory auditors and the external auditing firm, this was not able to protect the company from self-destruction. A direct analogy may be drawn between the cases of Enron and Parmalat, in terms of fraudulent activities and the companies' audit firms. However, for Enron to exist, Parmalat has survived its ordeal and has turned on the auditors in order to recover funds. Another difference is in the way that the auditing firms involved with Parmalat managed to extricate themselves from the crisis. However, Arthur Andersen was destroyed in the aftermath of Enron.

Melis (2005) highlighted a series of other serious corporate governance failures which led to the parmalat's crisis. Firstly, one of the non-executive directors in Parmalat was not independent as he had been working in Parmalat as a senior manager since 1963. Secondly, the chairman and chief executive position were not separated as was recommended by corporate governance codes of practice in Parmalat Finanziaria. Hence, both 
positions were held by Tanzi. Thirdly, the Preda corporate governance code in Italy specified that where a group of shareholders controls a company, it is even more important for some directors to be independent from the controlling shareholders. This was certainly not upheld by Parmalat. Also, there was no adequate explanation given by the company for this lack of compliance.

As in the case of Enron, the failure of Parmalat to establish careful checking and monitoring structures within the company's governance framework laid it bare to the abuse of power and fraudulent activity. Unless these devices for detecting fraud and misconduct are in place, it is relatively easy for Enron-like situation to arise.

Therefore, corporate governance in Italy was in sixth place as we can see in the graph below.

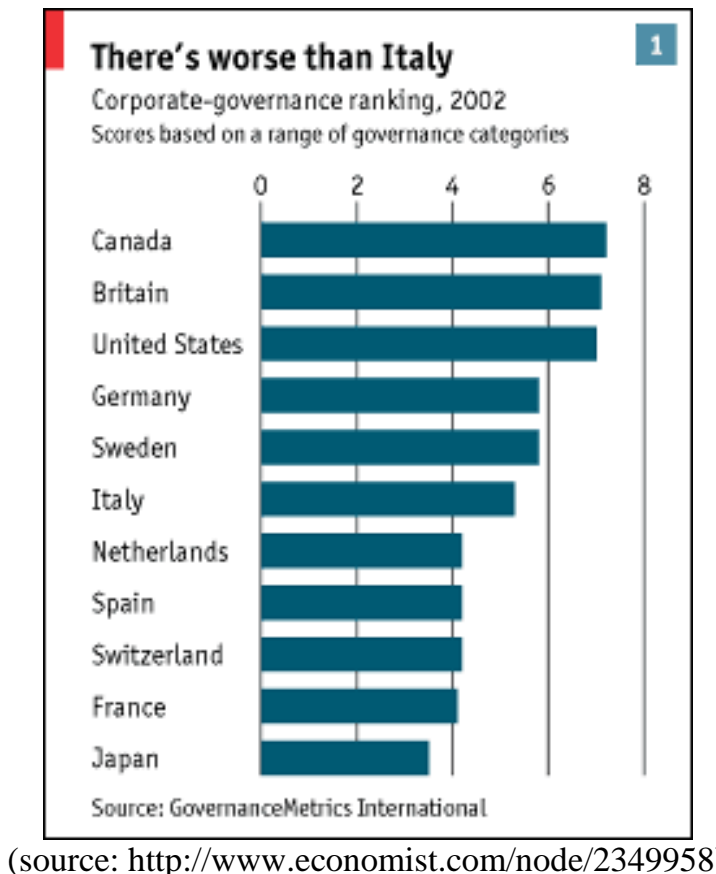

The Parmalat case may seem to differ in terms of the simplicity of its fraud. The audited statements from Bonlat were used to show cash balances that were reported by the parent company. Thus, it used in offsetting high levels of debt on its balance sheet. Each quarter with a set of forged documents would show purported cash holdings at Bonlat that matched the head office's requirements. Furthermore, Deloitte seems to have accepted Grant Thornton's audits unquestioningly. On the other hand, bankers and investors took the audited group figures as reassurance that, although complex, the group's finances were essentially sound. In addition, they failed 
to ask why a company with so much cash needed to borrow so much. (http://www.economist.com/node/2349958)

\section{Conclusion}

Corporate governance is the organizational arrangement by which a company represents and serves the interests of its investors. It encompasses anything from the company's boards to executive compensation schemes to bankruptcy laws.

Like the American cases, the Parmalat scandal has raised questions about how the company could fudge its numbers for so long without any help from outside. The auditors, says Mittelstaedt, should have least spoken to Bank of America to verify that they held the $\$ 4.9$ billion Parmalat claimed.

The system of checks and balances that support corporate governance needs to function effectively. Consequently, both Enron and Parmalat highlight the essential functions of non-executive directors, audit and disclosure, as well as ethicality of management. Corporate governance mechanisms cannot prevent unethical activity by top management. However, they can at least act as a means of detecting such activity by top management before it is too late. When an apple is rotten, it has no cure. Nevertheless, the rotten apple can be removed before the infection spreads and infects the whole barrel. Therefore, an analysis of the Enron and Parmalat cases shows that both the US and corporate governance systems are so different in character. Additionally, they can be vulnerable to abuse and corporate governance weaknesses which are similar in nature. This is really what effective corporate governance is all about. Therefore, this study aims to explore the various checks and balances, and mechanisms by which good corporate governance ensures successful business and social welfare maximization.

\section{References:}

Aduda, Chogii \& Magutu (2013). An empirical test of competiting corporate governance theories.

Aguilera \& Jackson (2011). Comparative and International Corporate Governance, SSRN.1-73.

Allen, Gale \& Wharton (2002). Financial Institutional Center. "A Comparative Theory of Corporate Governance”, December 22,, 1-27.

Analiza e Përgjegjësisë Sociale te Korporatave në Shqipëri.Prezenca e OSBE-së në Shqipëri dhe Ambasada e Kanadasë në Shqipëri, 2013

Anderson, Melanson \& Maly (2007). The Evolution of Corporate Governance: power redistribution brings boards to life. Corporate Governance, 15(5):780-797. 
Agyei \& Owusu (2014). The Effect of Ownership Structure and Corporate Governance on Capital Structure of Ghanaian Listed Manufacturing Companies.

Arrazola \& Hevia (2007). An aggregated index of human capital, research paper, Economic Buletin, volumi 10 (1), fq 1 - 11, URL: http://economics bulletin.vanderbilt.edu data e aksesit 06.06.2012.

Babic, Jelena \& Jelena (2010). Rethinking Board Role Performance: Toward An Integral Model (1-23).

Babić (2010). Corporate Governance in Transition Economics. Ekonomske teme, 34(2), 555,568.

Babić (2003). Corporate governance problems in transition economies, Winston-salem: Wake Forest University, Social Science Research Seminar. 